\title{
THE EFFECT OF YEAST EXTRACT ADDITION TO DOUGH ON THE FERMENTATIVE ACTIVITY OF SACCHAROMYCES CEREVISIAE
}

\section{UTICAJ DODATKA EKSTRAKTA KVASCA U TESTO NA FERMENTATIVNU AKTIVNOST SACCHAROMYCES CEREVISIAE}

\author{
Vesna M. VUČUROVIĆ*, Vladimir S. PUŠKA ̌́*, Urǒ̌ D. MILJIĆ*, Jelena S. FILIPOVIĆ**, Vladimir S. FILIPOVIĆ* \\ *Faculty of Technology, University of Novi Sad, Boulevard caraLazara 1, 21000 Novi Sad, Serbia \\ **Institute for Food Technology in Novi Sad, Boulevard caraLazara 1, 21000 Novi Sad, Serbia \\ e-mail:vvvesna@uns.ac.rs
}

\begin{abstract}
The purpose of this study is to examine the effect of bakery yeast extract (YE) addition, in the form of a paste (up to $10 \%$ to the wheat flour mass) on the fermentative activity (FA) of bakery yeast during dough preparation. The addition of YE in an amount of 1$5 \%$ had no statistically significant influence on the fermentative performance of Saccharomyces cerevisiae in dough. A further

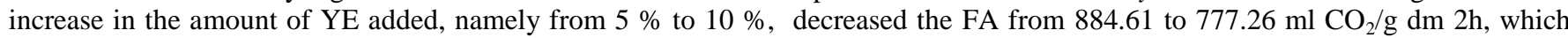
corresponds to $12.1 \%$. The decrease in FA with the addition of YE in an amount over $5 \%$ was much more pronounced in the second hour of the fermentation. Furthermore, YE was found to be an excellent source of protein (70.42 g/100 g of dry mass) and different minerals, especially $\mathrm{Mg}(513.91 \mathrm{mg} / \mathrm{kg}$ on a dry mass basis) and Ca (36.27 mg/kg), enabling the production of protein- and mineralenriched bread.
\end{abstract}

Key words: bakery yeast, Saccharomyces cerevisiae, fermentative activity, yeast extract

\section{REZIME}

Fermentativna aktivnost (FA) ćelija pekarskog kvasca u testu je jedan od ključnih faktora koji utiču na kvalitet finalnog hleba. Tokom fermentacije ćelije pekarskog kvasaca (Saccharomyces cerevisiae) proizvode $\mathrm{CO}_{2} \mathrm{i}$ druge metabolite koji utiču na reološke osobin testa i teksturu, zapreminu i ukus hleba. FA ćelija kvasca zavisi od različitih faktora, uključujući hemijski sastav testa, uslove fermentacije, soj primenjenog kvasca i uslove za rast kvasca. Ekstrakt kvasca je proizvod enzimske razgradnje sastojaka ćelija kvasca endogenim i egzogenim enzimima kvasca. Ekstrakt kvasca uglavnom se koristi u prehrambenoj industriji u proizvodnji supa, konzerviranih maslina, mesnih proizvoda i soseva, kao i poboljšanje ukusa finih pekarskih proizvoda i snek proizvoda.

Ovaj rad obuhvata ispitivanje dodatka različite količine ekstrakta pekarskog kvasca u obliku paste (do $10 \%$ na masu pšeničnog brašna) na FA kvasca u testu. FA ćelija kvasca praćena je merenjem mase $\mathrm{CO}_{2}$ izdvojene tokom dva sata fermentacije testa, pomoću SJA fermentografa. Zaključeno je da dodatak ekstrakta kvasca u količini od 1-5\% nema statistički značajnog uticaja na fermentivnu sposobnost kvasca u testu. Daljim porastom količine ekstrakta kvascasa 5\% na 10\% smanjuje se FA sa 884,61 na 777,26 ml CO $/ \mathrm{g}$ sm 2 h, što odgovara smanjenju od 12,1\%. Smanjenje FA kvasca sa dodatkom ekstrakta kvasca u količini preko 5\% bilo je značajno izraženije u drugom satu fermentacije. Analizom ekstrakta kvasca utvrđeno je da on predstavlja odličan izvor proteina (70,42 g/100 g na suve mase) i različitih minerala posebno $\mathrm{Mg}(513,91 \mathrm{mg} / \mathrm{kg})$ i Ca $(36,27 \mathrm{mg} / \mathrm{kg})$, čiji dodatak omogućava proizvodnju hleba obogaćenog proteinima i mineralima.

Ključnereči: fermentativna aktivnost, pekarski kvasac, Saccharomyces cerevisiae

\section{INTRODUCTION}

One of the most important phases in the bread making process is the yeast-mediated dough fermentation. During fermentation, baker's yeast cells (Saccharomyces cerevisiae) consume the fermentable sugars present in dough and generate carbon dioxide $\left(\mathrm{CO}_{2}\right)$, ethanol and secondary metabolites such as acetic acid, succinic acid, glycerol, and aroma compounds that are responsible for dough leavening during the fermentation phase and the oven rise (Struyf et al., 2017). The high fermentative activity (FA) of bakery yeast cells involves an intense release of $\mathrm{CO}_{2}$ in the dough (Vučurović et al., 2017). The generated $\mathrm{CO}_{2}$ causes the gluten to stretch and most of the gas is retained and trapped within the matrix producing bubbles, whereas the alcohol simply evaporates (Hutkins, 2006). The addition of certain nutrients, particularly organic nitrogen (amino acids) or inorganic nitrogen (ammonium salts), can enhance the viability and fermentation rate of bakery yeast. S. cerevisiae requires growth factors such as vitamins, nucleotides, amino acids, fatty acids, and sterol at low concentrations for specific catalytic processes or structural reasons. Yeast extract (YE) may be employed to supplement media and provide these growth factors (Walker and Stewart 2016). The effects of vitamins, minerals, amino acids and yeast extract addition on brewing and distilling fermentations are widely described in the scientific literature, whereas a limited body of information exists on their role in dough fermentation.

In modern bakery production, with a renewed interest in improving the nutritional values of foodstuffs with proteins, different sources of protein have been successfully used in formulations for high protein bread (Šimurina et al., 2015). Yeast extract (YE) is a concentrate of the dissolved fraction of yeast biomass, which is separated by filtration after the autolysis, plasmolysis or acid hydrolysis of fresh yeast biomass (Grba, 2010). YE most frequently results from the enzymatic digestion of yeast cell constituents by endogenous and exogenous yeast enzymes (Bekatrou et al., 2006). Degradative enzymes, generally compartmentalized within the living cell, are located in the general matrix of the cell. Hydrolytic enzymes, particularly protease and nuclease, break down insoluble macromolecules such as proteins and nucleic acids to soluble products of peptides, amino acids (mainly glutamate), nucleotides and amino 
acid derivates (Tanguler and Erten, 2008). Yeast extracts are used in food for two basic purposes: improving organoleptic properties (meat flavor) and increasing nutritive values (amino acids, nucleotides, vitamins and minerals) (Grba, 2010). Yeast extracts are mainly used in the food industry for providing a meaty flavor to soups, gravies, meat products and sauces, as well as for snack flavoring. Yeast extracts are commercially marketed as liquid, paste or powder (Tanguler and Erten, 2008).

Although yeast extract is known to be used as natural flavor enhancer in bakery production, there is a lack of knowledge about the effect of different amounts of this product on the fermentative activity of yeast in dough. Therefore, to our belief, this study is the first report on the effect of bakery yeast extract addition to dough on the fermentative activity of Saccharomyces cerevisiae, aimed at gaining the necessary knowledge about the production of nutritionally enriched bread.

\section{MATERIAL AND METHOD}

For an SJA fermentograph analysis, the dough was prepared using the domestic wheat flour T-500 (25 kg package) Sentella, Žitopromet-mlin A.D. Senta, the Republic of Serbia. Instant dry commercial baker's yeast, Saccharomyces cerevisiae, and yeast extract (YE) in the form of a paste were kindly provided by the same producer. The basic chemical analysis of these raw materials included the determination of protein content using the Micro-Kjeldahl metod (Nx6.25) (AOAC 962.52, 1994), starch content using the polarimetric Ewers method, cellulose content using the Weender method, lipid content using the Weibull Stold method, ash content using the gravimetric method (Službeni list SFRJ 1974/88), and the total sugar content using the LuffSchoorl method (Službeni list SFRJ 41/1987). Contents of Zn, $\mathrm{Cu}, \mathrm{Mg}, \mathrm{Ca}$, and $\mathrm{Fe}$ were determined using the accredited AAS method (FIINS lab. 5.4.3 -M -004/13 2011).

The FA was analyzed according to the Serbian standards methods (Službeni list SRJ br. 9/2002). The dough was prepared according to the following procedure: $280.00 \mathrm{~g}$ of flour preheated to $35{ }^{\circ} \mathrm{C}$ was transferred into a suitable enamel jug, which was also preheated at $35^{\circ} \mathrm{C}$. Instant bakery yeast (2.00 g) was added directly to the flour. YE in the form of a paste ( $1 \%$, $2.5 \%, 4 \%, 5 \%, 7.5 \%$ and $10 \%$ to the flour mass) was transfered by dissolving with $160 \mathrm{ml}$ of a table salt solution in tap water $(2.5 \% \mathrm{~m} / \mathrm{v})$ preheated at $35^{\circ} \mathrm{C}$. A laboratory mixer was used for ingredient mixing (during $5 \mathrm{~min}$ ) and dough formation. YE was not used in the control samples for dough preparation. Formed dough samples were placed into a preheated mold and transferred into the chamber at $35{ }^{\circ} \mathrm{C}$ of a SJA fermentograph device. The volume of $\mathrm{CO}_{2}(\mathrm{ml})$ released during the first hour of the dough fermentation was registered using the fermentograph plotter. Afterwards, the dough was hand mixed and returned to the chamber to monitor the volume of $\mathrm{CO}_{2}(\mathrm{ml})$ released during the second fermentation hour.

The experiments were conducted in triplicate, and the data were analyzed for statistical significance using the one-way analysis of variance (ANOVA). A probability of $5 \%(p=0.05)$ was used to accept or reject the null hypothesis. The statistical analysis was performed using the software Microsoft Office Excel 2010 for Windows.

\section{RESULTS AND DISCUSION}

The results of the chemical composition of wheat flour, instant bakery yeast and yeast extract in the form of a paste are presented in Table 1, whereas the mineral content in these raw materials is shown in Table 2.
Table .1 Chemical compositions of raw materials

\begin{tabular}{||c|c|c|c||}
\hline $\begin{array}{c}\text { Quality parameter } \\
(\mathrm{g} / 100 \mathrm{~g})\end{array}$ & $\begin{array}{c}\text { Wheat flour } \\
\text { T-500 }\end{array}$ & $\begin{array}{c}\text { Instant dry } \\
\text { bakery yeast }\end{array}$ & $\begin{array}{c}\text { Yeast } \\
\text { extractpaste }\end{array}$ \\
\hline water $(\mathrm{g} / 100 \mathrm{~g})$ & 12.26 & 3.99 & 36.5 \\
\hline dry mass $(\mathrm{g} / 100 \mathrm{~g})$ & 87.74 & 96.01 & 63.5 \\
\hline ash g/100 g dm) & 0.52 & 5.83 & 13.44 \\
\hline protein $(\mathrm{g} / 100 \mathrm{~g} \mathrm{dm})$ & 13.1 & 48.53 & 70.42 \\
\hline starch $(\mathrm{g} / 100 \mathrm{~g} \mathrm{dm})$ & 82.93 & 27.33 & 0 \\
\hline lipids $(\mathrm{g} / 100 \mathrm{~g} \mathrm{dm})$ & 1.24 & 0.62 & 0.21 \\
\hline sugar $(\mathrm{g} / 100 \mathrm{~g} \mathrm{dm})$ & 1.38 & 14.23 & 8.17 \\
\hline cellulose $(\mathrm{g} / 100 \mathrm{~g} \mathrm{dm})$ & 0.12 & - & - \\
\hline \hline
\end{tabular}

Table 2. Mineral content of raw materials

\begin{tabular}{|c|c|c|c||}
\hline Mineral & $\begin{array}{c}\text { Wheat flour } \\
\text { T-500 }\end{array}$ & $\begin{array}{c}\text { Instant dry } \\
\text { bakery yeast }\end{array}$ & $\begin{array}{c}\text { Yeast } \\
\text { extractpaste }\end{array}$ \\
\hline $\mathrm{Cu}(\mathrm{mg} / \mathrm{kg})$ & 1.96 & 5.95 & 1.98 \\
\hline $\mathrm{Zn} \mathrm{(mg/kg)}$ & 4.14 & 56.09 & 39.73 \\
\hline $\mathrm{Mg}(\mathrm{mg} / \mathrm{kg})$ & 244.81 & 526.71 & 513.91 \\
\hline $\mathrm{Ca} \mathrm{(mg/kg)}$ & 169.74 & 41.16 & 36.27 \\
\hline $\mathrm{Fe} \mathrm{(mg/kg)}$ & 8.84 & 48.26 & 38.28 \\
\hline
\end{tabular}

Its chemical and mineral composition is in agreement with the standard instant dry yeast quality (Kulp and Lolenz, 2003). As expected, the dry mass of YE was composed mostly of proteins. A high protein content of the YE dry mass (70.42 g/100 $\mathrm{g} \mathrm{dm}$ ), corresponding to $47.4 \mathrm{~g} / 100 \mathrm{~g}$ proteins in the YE paste, indicated that this product is a valuable source of proteins. The results obtained in this research are consistent with the data published in previous studies (Chae et al., 2001; Saksinchai et al., 2001, Tanguler and Erten, 2008), in which the protein content of yeast extract recorded was 41.0-61.3 g/100 g dm. The ash content in YE (13.44 g/100 g dm) indicates its potential as a source of mineral compounds. Moreover, the mineral composition of YE suggests that it is a valuable source of $\mathrm{Mg}$ (51.96 mg/kg), Zn (36.27 mg/kg), Fe (38.28 mg/kg), Ca (36.27 $\mathrm{mg} / \mathrm{kg}$ ). These results imply that the addition of YE to dough can enhance the nutritive value of bakery products.

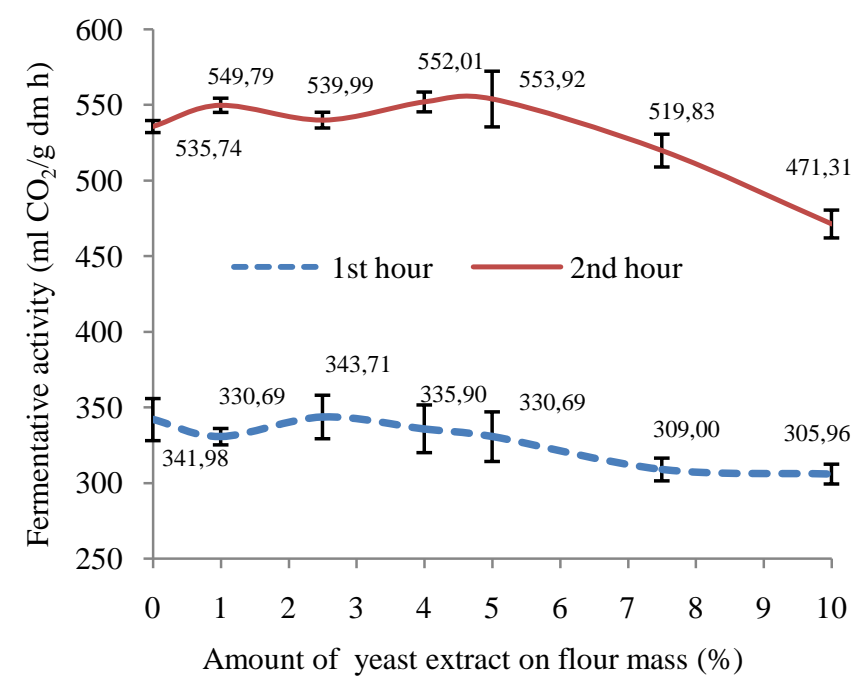

Fig. 1. Fermentative activity of instant dry bakery yeast released during the first and the second hour of dough fermentation 


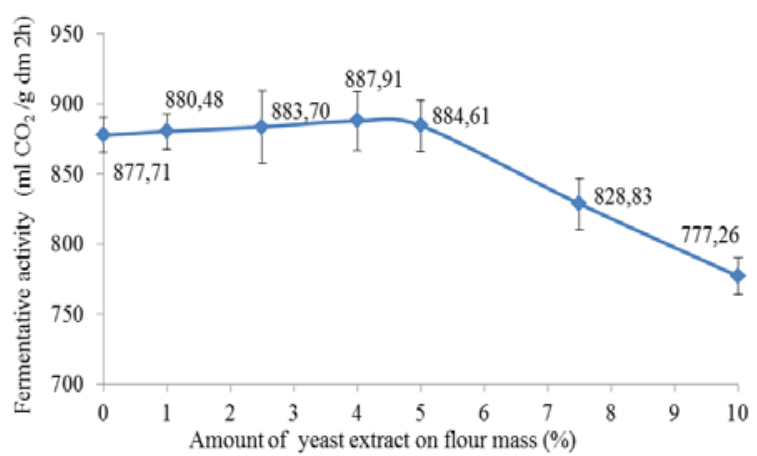

Fig. 2. Fermentative activity of instant dry bakery yeast released during the two hours of dough fermentation

The fermentative activity (FA) of instant dry bakery yeast, which represents the volume of $\mathrm{CO}_{2}(\mathrm{ml})$ produced by one gram of the yeast dry mass, released during the first and the second hour of the dough fermentation is presented in Figure 1.As shown in Fig. 1, the FA of yeast was significantly higher in the second than in the first hour of fermentation in all the dough samples examined. Furthermore, it is evident that the addition of YE in an amount of up to $5 \%$ exerted no significant effect on the FA of yeast in both hours of fermentation. Conversely, the addition of YE in amounts of $7.5 \%$ and $10 \%$ caused a significant decrease in the FA. Increasing the amount of YE from $5 \%$ to $7.5 \%$ and $10 \%$ in the first fermentation hour, the FA was decreased from an average value of $330.69 \mathrm{ml} \mathrm{CO}_{2} / \mathrm{g} \mathrm{dm}$ to $309.00 \mathrm{ml} \mathrm{CO} / \mathrm{g} \mathrm{dm}$ and $305.96 \mathrm{ml} \mathrm{CO} / \mathrm{g} \mathrm{dm}$, respectively. An increase in the YE amount in the dough from $5 \%$ to $7.5 \%$ and $10 \%$ in the second hour of fermentation decreased the FA from $553.92 \mathrm{ml} \mathrm{CO}_{2} / \mathrm{g} \mathrm{dm}$ to $519.83 \mathrm{ml} \mathrm{CO}_{2} / \mathrm{g} \mathrm{dm}$ and $471.31 \mathrm{ml}$ $\mathrm{CO}_{2} / \mathrm{g} \mathrm{dm}$. With an increase in the YE amount from $5 \%$ to $10 \%$ in the first hour, the FA was decreased for $21.70 \mathrm{ml} \mathrm{CO}_{2} / \mathrm{g} \mathrm{dm}$ (corresponding to $6.8 \%$ ), whereas in the second hour it was decreased for $84.06 \mathrm{ml} \mathrm{CO} / \mathrm{g} \mathrm{dm}$ (corresponding to $15.0 \%$ ). The comparison of these results indicates that a decrease in FA with the YE amount increasing from $5 \%$ to $10 \%$ was much more pronounced in the second hour of fermentation. The FA results during the two hours of fermentation are presented in Figure 2. Observing the total volume of $\mathrm{CO}_{2}$ produced during both hours of dough fermentation, it is noticeable that the addition of YE in an amount of 1-5 \% had no statistically significant influence on the fermentative performance of Saccharomyces cerevisiae in dough. A further increase of YE amount from $5 \%$ to $10 \%$ decreased the FA during the $2 \mathrm{~h}$ fermentation from 884.61 to $777.26 \mathrm{ml} \mathrm{CO}_{2} / \mathrm{g} \mathrm{dm} 2 \mathrm{~h}$, which corresponds to a decrease in the total $\mathrm{CO}_{2}$ volume from $6.3 \%$ to $12.1 \%$ respectively.On the basis of the results obtained, YE in the form of a paste can be added to dough in an amount of up to $5 \%$ (to the wheat flour mass) for bakery product preparation with no effect on the fermentative activity of Saccharomyces cerevisiae cells. A further increase in yeast extract amount up to $10 \%$ decreases the fermentative activity of yeast up to $12.1 \%$. The addition of $5 \%$ of yeast extract to the wheat flour mass entails the nutritional enrichment of baked goods with $35.2 \mathrm{~g}$ proteins, $257 \mathrm{mg} \mathrm{Mg}, 20 \mathrm{mg} \mathrm{Zn}, 19 \mathrm{mg}$ Fe and $18 \mathrm{mg}$ Ca per one $\mathrm{kg}$ of wheat flour. Therefore, further investigation is needed to explore the effect of YE addition on the quality of final bakery products. The production of bakery products enriched with YE using different types of flour such as spelt flour (Košutić et al., 2015) will be the focus of our future research.

\section{CONCLUSION}

Yeast extract in the form of a paste can be added to dough in an amount of up to $5 \%$ to the wheat flour mass for bakery products with no effect on the fermentative activity of Saccharomyces cerevisiae cells. Consequently, bakery goods are enriched with 35.2 g proteins, 257 mg Mg, 20 mg Zn, 19 mg Fe and $18 \mathrm{mg}$ Ca per one $\mathrm{kg}$ of wheat flour. Increasing the amount of yeast extract from $5 \%$ to $10 \%$ decreases the FA from 884.61 to $777.26 \mathrm{ml} \mathrm{CO}_{2} / \mathrm{g} \mathrm{dm} 2 \mathrm{~h}$, which corresponds to a decrease in the total $\mathrm{CO}_{2}$ volume from $6.3 \%$ to $12.1 \%$ respectively.

ACKNOWLEDGMENT: The financial support of the project TR-31002, entitled "Improving Bioethanol Production from Products of Sugar Beet Processing", from the Ministry of Science and Technological Development of the Republic of Serbia is highly acknowledged.

\section{REFERENCES}

AAS - Fins.lab. 5.4.3 -M -004/13 (2011).

Association of official Analytical Chemists International, Gaithersburg, AOAC (1994). Official method: 962.52.

Bekatrou, A., Psarianos, C., Koutinas A.A. (2006). Production of Food Grade Yeasts. Food Technology and Biotechnology, 44 (3), 407-415.

Chae, H.J., Joo, H., In, M.-J. (2001). Utilization of brewer's yeast cells for the production of food-grade yeast extract. Part I: Effects of different enzymatic treatments on solid and protein recovery and flavor characteristics. Bioresource Technology, 76, 253-258.

Grba, S. (2010). Kvasci u biotehnološkoj proizvodnji. Prehrambeno-biotehnološki fakultet Sveučilišta u Zagrebu, Republika Hrvatska.

Hutkins, R. W. (2006). Microbiology and Technology of Fermented Foods, Blackwell Publishing, Chapter 8, 128-129.

Košutić, M., Filipović, J., Ivkov, M. (2015). Spelt pasta with functional components and consumers acceptance. Journal on processing and energy in Agriculture, 19 (5), 263-265.

Kulp, K., Lorenz, K. (2003). Handbook of dough fermentations Colorado State University, Fort Colins, Colorado USA.

Saksinchai, S., Supthantharica, M., Verduyn, C. (2001). Application of a simple yeast extract from spent brewer's yeast for growth and sporulation of Bacillus thuringiensis subsp. kurstaki: a physiological study. World Journal of Microbiology and Biotechnology, 17, 307-316.

Šimurina, O., Brkljača, J., Krulj, J., Jambrec, D., Filipčev, B., Jevtić Mučibabić, R., Pestorić, M. (2015). Properties of wholemeal spelt dough and bread enriched with plant proteins. Journal on Processing and Energy in Agriculture 19 (5), 236240.

Stryf, N., Van der Malen, E., Hemdane, S., Verspreet, J., Verstrepen, J.K., Courtin, C. M. (2017). Bread Dough and Baker's Yeast: An Uplifting Synergy, Comprehensive Reviews in Food Science and Food Safety, 16, 850-867.

Tanguler,H., Erten, H. (2008). Utilisation of spent brewer's yeast for yeast extract production by autolysis: The effect of temperature. Food and Bioproducts processing 86, 317-321.

Vučurović, V., Puškaš, S., Miljić, U., Muzalevski, A. (2017). The influence of table salt, white sugar complex bakery additive on the fermentative activity of Saccharomyces cerevisiae. Journal on Processing and Energy in Agriculture, 14 (1), 46-49.

Walker, G. M., Stewart, G. G. (2016). Saccharomyces cerevisiae in the production of fermented beverages. Beverages 2, 30-42.

Pravilnik o kvalitetu i drugim zahtevima za pekarski kvasac (Službeni list SRJ, br. 9/2002).

Pravilnik o metodama fizickih i hemijskih analiza za kontrolu kvaliteta žita, mlinskih i pekarskih proizvoda, testenina I brzo smrznutih testa (Službeni list SFRJ" broj 74/88).

Pravilnik o metodama uzimanja uzoraka i metodama vršenja hemijskih i fizickih analiza kakao-zrna, kakao proizvoda, proizvoda sličnih čokoladi, bombonskih proizvoda, kremproizvoda, keksa i proizvoda srodnih keksu (Službeni list SFRJ" 41/87).

Received: 03. 02. 2018.

Accepted: 12. 08. 2018. 